\title{
SEVERE COMMUNITY-ACQUIRED PNEUMONIACAUSED BY MYCOPLASMA PNEUMONIAE IN YOUNG FEMALE PATIENT
}

\author{
Milacic Nena, ${ }^{1}$ Djurovic Marija, ${ }^{2}$ Hasanbegovic Mirha, ${ }^{3}$ Milacic Bojan, ${ }^{4}$ Stevanovic Dragana ${ }^{5}$ \\ ${ }^{1}$ Department of Internal Medicine, Clinical Centre od Montenegro, Podgorica, Montenegro \\ ${ }^{2}$ Department of Gastroenterology, Clinical Centre of Montenegro, Podgorica, Montenegro \\ ${ }^{3}$ Department of Internal Medicine, General Hospital Pljevlja, Montenegro \\ ${ }^{4}$ Department of Thoracic Surgery, Clinical Center of Montenegro, Podgorica, Montenegro \\ ${ }^{5}$ Department of Radiology, General Hospital Bar, Montenegro
}

Primljen/Received 23. 06. 2015. god.

Abstract: Mycoplasma pneumonia is common agent causing community acquired pneumonia in younger population. However, the course of illness is usually benign and is rarely associated with pulmonary complications. We report a 27 years old female patient with unilateral pneumonia followed by pleural effusion and adhesions on the same side. This potential source of infection should be considered in young patients where resolution of symptoms from pneumonia is delayed.

Key words: Mycoplasma pneumoniae, community acquired pneumonia, pleural effusion, pleural adhesions.

\section{INTRODUCTION}

M. pneumoniae infection is one of the most common causes of atypical community acquired pneumonia (1). Pneumonia due to M. pneumoniae is usually mild and it is not infrequently that infection itself is asymptomatic. M. pneumoniae accounts for up 35\% of cases of pneumonia in outpatients and is responsible for $3-18 \%$ of cases in patients who require hospitalization (2). It has not real cellular wall, but three layer membrane, so penicillin can not be effective against this agent.

Infection is mostly spread by droplet transmission, being spread aerogenically in smaller closed spaces. Incubation time from Mycoplasma infection to first symptoms appearance takes from 14 to 21 days. The most common affected individuals are adolescents and younger persons by age of 30 years (3).

It is uncommon for M. pneumoniae to present in a fulminant and fatal manner $(2,3,4)$. The fatal compli-
Prihvaćen/Accepted 18. 07. 2015. god.

cations of M. pneumonia infection are not well established but include acute respiratory distress syndrome, acute disseminated encephalomyelitis (ADEM), DIC, hemophagocytic syndrome and Stevens Johnsons syndrom. Rare cases of fatal myocarditis have been reported.

This infective agent has two very expressed pathogenic mechanisms: the first one reffers to strong affinity to respiratory tract cells (damages ciliary activity), the second one is capability of hydrogen peroxide production which initially damages respiratory tract lining cells, but also erythrocite membranes.

Initiation is almost obscure followed by symptoms originating from upper respiratory tract, subfebrile temperatures, shivering, headaches. After few days attacks of dry irritating cough appear, which lead to choking. Physical examination of lungs is most commonly normal. Symptoms appear only a week after, sometimes even latter, when inspiratory or expiratory crackles can be heard on lung auscultation.

Diagnostics consists of standard laboratory blood tests, serological testing, chest X-ray.

Radiological finding may manifest multiform patterns: unilaterally bronchopneumonic band-forming, blotchy infiltrates in lower pulmonary fields followed by plate atelectases, nodular shadows, hillary adenopathy, unilateral pleural effusions too.

Treatment is based on use of macrolides, tetracyclines and chinolones (5).

\section{CASE PRESENTATION}

A 27 years old female with no significant past medical history, smoker, working as hairdresser, was ad- 
mitted to Pulmology Department through Urgent centre for increased body temperature, dry irritating cough, dyspnea, general feeling unwell and malaise. Symptoms appeared eight days before, in much less expressed form. Initially increased body temperature, by 37,5 degrees, nasal secretion and pain in region of frontal sinuses, shiver and trembling were present. During the course of disease patient has been normally doing her daily activities. Consequently, symptoms become more intensive with very intensive persisting cough, severe dyspnea, general malaise and exhaustion, due to which patient was initially observed and diagnotically investigated in Urgent centre. C-reactive protein 227 , hemoglobin $53 \mathrm{~g} / 1$. Chest X-ray verified infiltrative change in projection of lung on left in lower pulmonary lobe with pleural effusion. In personal history she denied diseases of hereditary significance, but she told she was ambulatory treated 15 days prior to admission due to bronchitis.

On admission she was conscious, oriented, easily dispnoic, febrile $(38,3)$, hypotensive, adinamic, had pale skin, many herpetic changes on the upper lip, with no signs of active haemorrhagic syndrome and significant peripheral lymphadenopathy. At the lung base on left decreased breath sound without pathological accompanied sounds. Cardiac action was rhythmic, sounds clear, without murmur. Her blood pressure was $110 / 70 \mathrm{mmHg}$, pulse $130 \mathrm{bpm}$, oxygen saturation $88 \%$. EKG showed sinus rhythm, frequency of 75 in minute, without significant changes on ST segment. Remaining of physical examination was regular.

During hospitalization she remains easily dispnoic, febrile (37,5), adinamic. Significant findings in her hospital course are as follows: SR 54, WBC 6,2, RBC 3,59, MCV 52,6, HGB 53, TR 186, CRP 227,7, IL-6 28,0, D DIMER 4,99. Arterial blood gas showed $\mathrm{pH}$ 7,43, pC02 3,89 kPa, pO2 7,3 kPa, oxygen saturation



Figure 1. The first patient's chest X-ray
$88,8 \%$. GGT 364, remaining laboratory findings in referral frame values. Patient was sampled for Influenza viruses $\mathrm{A}$ and $\mathrm{B}$. Immunoserological analyses were performed for Chlamydia trachomatis, Mycoplasma pneumonia, Coxiella burnetti and Legionella pneumophila. Sputum was taken for cultivation. Combining parenteral antibiotic therapy was initiated $\left(3^{\text {rd }}\right.$ generation cephalosporin and amynoglicoside), yet remaining symptomatic and supportive therapy. On abdomen ultrasound pathological changes were not detected, as on ultrasound of thyroid gland. Gastroenterologist consulted, indicated EGDS and screening on celiakia. Normal finding on gynecological examination. Coombs tests negative, vitamin B12, beta 2 microglobuline, hemostasis parameters level in referral values. Iron serum level decreased - 3,9, TIBC 37,1, UIBC 33,2, transferin 1,58, s-transferin 10, sTIR 4,23, FRT 197,0, haptoglobin 5,42. Peripheral blood smear revealed hypochromic neutrophilia with toxic granulations. Hormonal status and tumor markers in normal range. She received two doses of deplasmated erythrocytes. However, symptoms of the same intensity persisted followed by pain in region of rib arches on left side. Control CRP did not show significant decline (CRP 218), control chest X-ray showed persisting parenchyma consolidation in projection of lower pulmonary lappet with same side pleural effusion on left.



Figure 2. The second patient chest X-ray

MSCT of chest confirmed infiltrative change in pulmonary parenchyma on left in projection of lower lobe anterobasically accompanied by pleural adhesions and small amount of pleural effusion on the same side. Due to all the above mentioned, change in antimicrobial therapy was indicated (combination of carbapenems and chinolons).

Three days after this therapy was administered, subjective improvement was achieved, as the same of inflammatory markers level decreasement (Se 50, CRP 


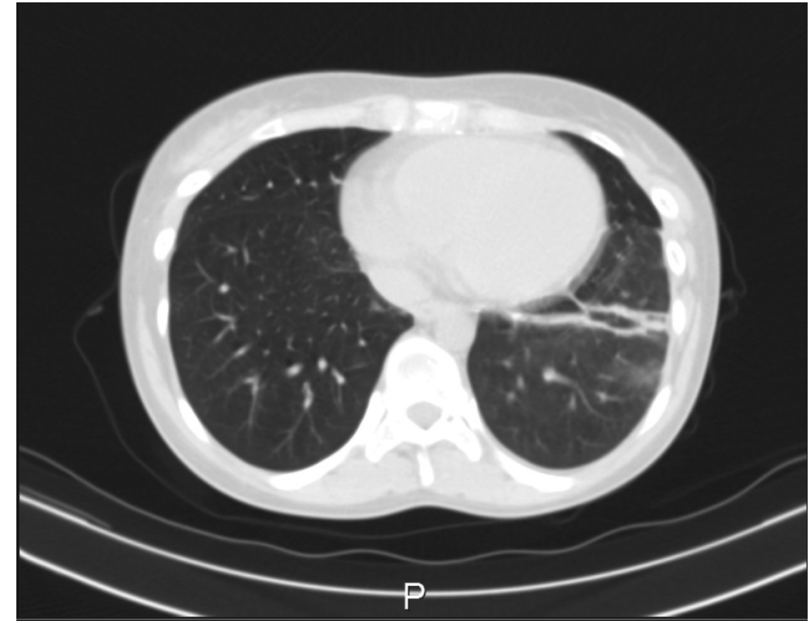

Figure 3. MCST of patients's chest

90, fibrinogen 5,2), control D-dimer 1,59. Immunoserological tests verrified IgM antibodies against Mycoplasma pneumonia. Sputum culture showed unspecified result. Tests on Influenza A and B negative, the same of celiakia screening. Patient refused to perform suggested esophagogastroscopy. Same antimicrobial therapy was continued. On control chest X-ray earlier described condensation of pulmonary parenchyma was verrified on left in projection of lower pulmonary lobe in significant regression. Control inflammatory markers showed decline (CRP 4,5, fibrinogen 4,3). During hospitalization increasement in platelet count was found in blood count $(\operatorname{Tr} 186 \ldots 255 \ldots 827 \ldots$ 935), possibly reactive phenomenon regarding existing anemia and mentioned pleuropnemonia on left. Patient was physically examined in ambulance one week after discharge. She denied any discomfort, while control chest $\mathrm{X}$-ray showed complete regression of earlier described change in lung on left.

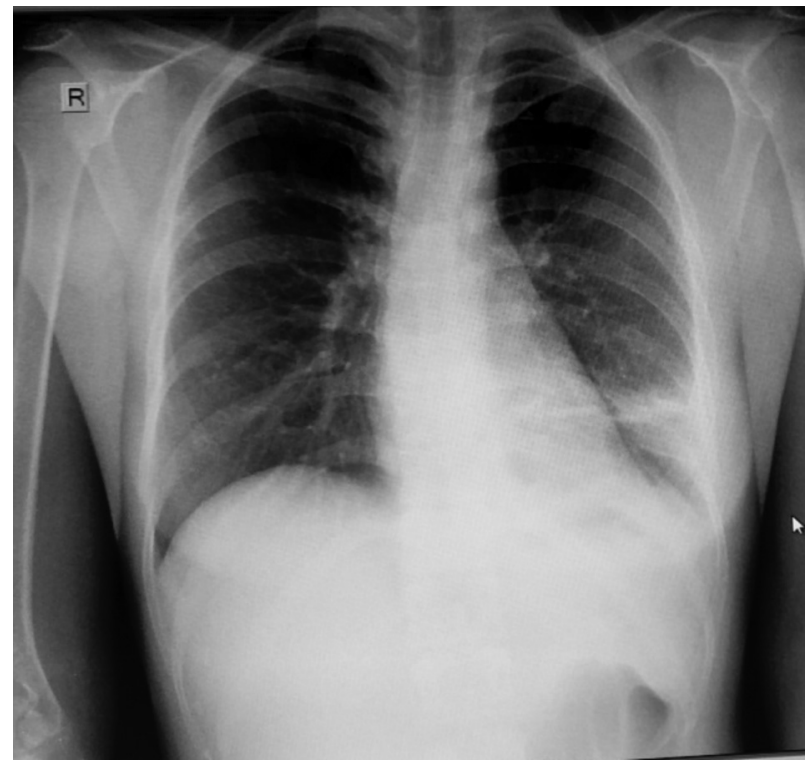

Figure 4. Control chest X-ray

\section{DISCUSSION AND CONCLUSIONS}

The most common cause of community acquired pneumonia in population by years of 30 is Mycoplasma pneumoniae. It runs often mild course and those patients are usually treated as outpatients. However, MP pneumonia can lead to complications, among them the most often are unilateral small amount parapneumonic effusions, but also bilateral pneumonia, ARDS, respiratory insufficiency. Pleural effusion, if it occurs, is usually a small amount of effusion which is self limi$\operatorname{ting}(1,2,3)$.

The demonstration of elevated IgM antibodies by either indirect immunoflorescence or EIA is required for the diagnosis. Alternatively, a fourfold increase in IgG antibodies by Complement Fixation Test or EIA can also provide the diagnosis (4). The recommended therapy for mycoplasma infection is a 10 day course of clarithromycin or five day course of Azithromycin. Other drugs which can be effective include tetracyclines and chinolons (5).

In our patient the symptoms did not resolve and inflammatory markers did not decline despite initial intervention $(5,6,7)$, which was not appropriate one, leading to further examination and differential diagnosis which indicated MP as the cause of the patient's symptoms. After introducing of appropriate antibiotic tretament, general patient state improves, inflammatory markers decline, radiological chest finding shows regression of changes.

Clinicians should be aware of potential pneumonia in younger patients due to atypical pathogens, which are resistant to initial empirical antibiotic therapy (cephalosporines, penicillins). Without adecquate antibiotic treatment in such a case, parapneumonic effusions, which can further lead to other respiratory complications, occur. Early diagnosis and appropriate therapy (macrolides, chinolons, tetracyclines) can prevent bad patient's outcome.
Abbreviations:
DIC - disseminated intravascular coagulation
ADEM - acute disseminated encephalomyelitis mmHg - millimetres of mercury
bpm - beats per minute
SR - sedimentation rate
WBC — white blood cells
RBC - red blood cells
MCV - mean corpuscular volume
HGB - hemoglobin
PLT - platelets
CRP - C-reactive protein 
IL-6 - interleukin 6

$\mathrm{pH}$ - potential hydrogen

pO2 - partial pressure of oxygen

pCO2 - partial pressure of carbon dioxide

GGT - gamma-glutamyl transferase
EGDS - esophagogastroduodenoscopy

TIBC — total iron binding capacity

UIBC — unbound iron binding capacity

sTIR — short inversion time recovery

EIA - enzyme immunoassay

\title{
Sažetak
}

\section{TEŠKA VANBOLNIČKI STEČENA PNEUMONIJA UZROKOVANA MIKOPLAZMOM PNEUMONIJE U MLADE PACIJENTKINJE}

\author{
Milačić Nena, ${ }^{1}$ Đurović Marija, ${ }^{2}$ Hasanbegović Mirha, ${ }^{3}$ Milačić Bojan, ${ }^{4}$ Stevanović Dragana \\ ${ }^{1}$ Interna klinika, Odjeljenje pulmologije, Klinički centar Crne Gore, Podgorica, Crna Gora \\ ${ }^{2}$ Interna klinika, Odjeljenje gastroenterologije, Klinički centar Crne Gore, Podgorica, Crna Gora \\ ${ }^{3}$ Odjeljenje interne medicine, Opšta bolnica Pljevlja, Crna Gora \\ ${ }^{4}$ Hirurška klinika, Odjeljenje za grudnu hirurgiju, Klinički centar Crne Gore, Podgorica, Crna Gora \\ ${ }^{5}$ Odjeljenje radiologije, Opšta bolnica Bar, Crna Gora
}

Mycoplasma pneumoniae je čest agens koji uzrokuje pneumoniju stečenu u zajednici kod mlađe populacije. Međutim, tok bolesti je obično benigan i retko udružen sa plućnim komplikacijama. Mi prikazujemo slučaj 27-ogodišnje pacijentkinje sa unilateralnom pneumonijom praćenom pleuralnom efuzijom $i$ adhe-

\section{REFERENCES}

1. Ćirić Zorica. Vanbolničke pneumonije. In: Pejčić T, editor. Pneumonije danas. 1st ed. Medicinski fakultet Univerziteta u Nišu, Grafika Galeb-Niš; 2013. p.13-33.

2. Powel DA. Nelson Textbook of Pediatrics. 19th ed. Philadelphia, Saunders, 2010; 1029-32.

3. Nastasijević Borovac D. Definicija, epidemiologija i klasifikacija pneumonija. In: Pejčić T, editor. Pneumonije danas, 1st ed. Niš: Grafika Galeb-Niš; 2013. p. 5-12. zijama na istoj strani. Ovaj potencijalni uzrok infekcije bi trebalo biti razmatran u mlađih pacijenata gde je rezolucija simptoma od pneumonije odložena.

Ključne reči: Mycoplasma pneumoniae, pneumonija stečena u zajednici, pleuralni izliv, pleuralne adhezije.

4. Nastasijević Borovac D. Biomarkeri inflamacije kod bolesnika sa pneumonijama. In: Pejčić T, editor. Pneumonije danas. 1st ed. Niš: Grafika Galeb-Niš; 2013. p. 185-210.

5. Kashyap S, Sarkar M. Mycoplasma pneumonia: Clinical features and management. Lung India. 2010; 7(2): 75-85.

6 . Youn YS, Lee KY. Mycoplasma pneumoniae pneumonia in children. Korean J Pediatr. 2012; 55(2): 42-7.

7. Kong MX, Newman K, Goldenberg R, Tierno PM, Mikolaenko I, Rapkiewicz A. Fatal Mycoplasma Pneumoniae Infection: Case Report and Review of the Literature. NAJ Med Sci. 2012; 5(2): 126-30.

\section{Correspondence to/Autor za korespondenciju}

Nena Milačić

Depatment of Internal medicine, Clinical Centre of Montenegro

Moskovska bb, 81000 Podgorica, Montenegro

Email: nena.milacic75@gmail.com 